\title{
Association between furosemide in premature infants and sensorineural hearing loss and nephrocalcinosis: a systematic review
}

\author{
Wesley Jackson ${ }^{1 *}$ D, Genevieve Taylor ${ }^{1}$, David Selewski ${ }^{2}$, P. Brian Smith³ ${ }^{3}$ Sue Tolleson-Rinehart ${ }^{1,4}$ \\ and Matthew M. Laughon'
}

\begin{abstract}
Furosemide is a potent loop diuretic commonly and variably used by neonatologists to improve oxygenation and lung compliance in premature infants. There are several safety concerns with use of furosemide in premature infants, specifically the risk of sensorineural hearing loss (SNHL), and nephrocalcinosis/nephrolithiasis (NC/NL). We conducted a systematic review of all trials and observational studies examining the association between these outcomes with exposure to furosemide in premature infants.

We searched MEDLINE, EMBASE, CINAHL, and clinicaltrials.gov. We included studies reporting either SNHL or NC/NL in premature infants ( $<37$ weeks completed gestational age) who received at least one dose of enteral or intravenous furosemide. Thirty-two studies met full inclusion criteria for the review, including 12 studies examining SNHL and 20 studies examining NC/NL. Only one randomized controlled trial was identified in this review. We found no evidence that furosemide exposure increases the risk of SNHL or NC/NL in premature infants, with varying quality of studies and found the strength of evidence for both outcomes to be low. The most common limitation in these studies was the lack of control for confounding factors.

The evidence for the risk of SNHL and NC/NL in premature infants exposed to furosemide is low. Further randomized controlled trials of furosemide in premature infants are urgently needed to adequately assess the risk of SNHL and NC/NL, provide evidence for improved FDA labeling, and promote safer prescribing practices.
\end{abstract}

Keywords: Furosemide, Infant, Premature, Sensorineural hearing loss, Nephrocalcinosis, Nephrolithiasis

\section{Background}

Furosemide is a potent diuretic that acts in the proximal and distal tubules, as well as the loop of Henle, to inhibit sodium and chloride reabsorption in the kidneys. The use of diuretics such as furosemide may alleviate symptoms associated with volume overload, including pulmonary edema. In premature infants, early pulmonary edema and excessive intravenous fluid administration are associated with an increased risk of bronchopulmonary dysplasia (BPD), also called chronic lung disease of prematurity $[1,2]$. Therefore, furosemide may be part of

\footnotetext{
* Correspondence: wesley.jackson@unchealth.unc.edu

'Division of Pediatrics, University of North Carolina at Chapel Hill, UNC

Hospitals 101 Manning Dr. 4th Floor, Chapel Hill, NC CB 7596, USA

Full list of author information is available at the end of the article
}

a clinical approach to reducing the risk of BPD in premature infants.

The Food and Drug Administration (FDA) has approved furosemide for the treatment of edema associated with congestive heart failure, cirrhosis, and nephrotic syndrome in children and adults. Furosemide is not approved by the FDA for use in premature infants and, as a result, any use in this population is considered off-label. Specifically, the FDA label for furosemide includes a warning that infants $<31$ weeks postmenstrual age receiving doses $>1 \mathrm{mg} / \mathrm{kg} /$ day intravenously may develop plasma levels resulting in ototoxicity. The label also notes that renal function monitoring and renal sonography should be considered in premature infants, as furosemide may precipitate nephrocalcinosis. 
The primary safety concern of furosemide use in premature infants is sensorineural hearing loss (SNHL). The incidence of SNHL is approximately $0.7-1.5 \%$ among infants admitted to the NICU and is more common in infants born prematurely [3, 4]. The association of SNHL and furosemide relies heavily on studies conducted in adults receiving high doses of furosemide. In one study, reversible hearing loss occurred in $50 \%$ of adult patients with uremia given a single $1000 \mathrm{mg}$ intravenous dose of furosemide, which is 50 times the usual adult dose [5]. A case series reported transient deafness in 3 adult patients with renal impairment given intravenous doses of 2000-3000 mg [6]. Finally, a trial of 19 adult patients receiving furosemide or placebo resulted in one patient with permanent deafness who had received 14 days of $1000 \mathrm{mg}$ per day. The authors of the trial reported that furosemide levels $>100 \mu \mathrm{g} / \mathrm{mL}$ were associated with ototoxicity [7]. The proposed mechanisms for furosemide-induced ototoxicity include changes in potassium concentrations in the cochlear endolymph and impairment of cellular proliferation $[8,9]$.

Furosemide use in premature infants has also been implicated in the development of nephrocalcinosis and nephrolithiasis, or renal calcifications and stones, although the etiology in this population is likely to be multifactorial $[10,11]$. Nephrocalcinosis is diagnosed by renal ultrasonography and has the appearance of increased echogenicity in the medullary pyramids of the kidney. Renal calculi, or nephrolithiasis, are detected on ultrasound by echogenic foci in the calyces or renal pelvis. Loop diuretics, such as furosemide, reduce renal tubular reabsorption of calcium resulting in hypercalciuria, which is the proposed mechanism for its association with nephrocalcinosis. However, this association is often confounded by concomitant exposure to other therapies, such as dexamethasone, long-term parenteral nutrition, and mechanical ventilation, which have been identified as risk factors for renal calcifications [12, 13].

In the absence of robust data from large, well-powered clinical trials, the best available method for evaluating the safety of furosemide in premature infants includes a thorough review of the limited number of randomized control trials, as well as non-controlled studies such as cohort and case-control studies. This systematic review will synthesize all trials and observational studies in which premature infants were exposed to at least one dose of furosemide and report on the following outcomes: SNHL and nephrocalcinosis/nephrolithiasis (NC/ $\mathrm{NL}$ ). This review differs from Cochrane reviews in its inclusion of observational studies, which comprise the majority of available evidence for furosemide safety in premature infants. The key questions this systematic review will address are the following:
Key Question 1: Does exposure to furosemide in premature infants increase the risk of SNHL? Key Question 2: Does exposure to furosemide in premature infants increase the risk of $\mathrm{NC} / \mathrm{NL}$ ?

\section{Methods}

We reviewed all observational cohort studies or clinical trials in which premature infants $(<37$ weeks completed gestational age) were exposed to at least one dose of furosemide while hospitalized in the NICU. We used premature infants without exposure to furosemide, when available, as comparators. The outcomes of interest were SNHL and NC/NL. Table 1 displays the eligibility criteria for this systematic review.

We searched the following databases for the relevant literature published in English: MEDLINE, EMBASE, and CINAHL. We also searched clinicaltrials.gov to include results of unpublished studies. The references of relevant articles within this search were reviewed by the investigators for additional articles of interest. The date of the most recent search was February 3, 2018. The MEDLINE search used the following Medical Subject Heading terms: "furosemide" AND "infant, premature." The final search included the following string of search terms: "furosemide" [MeSH Terms] OR "furosemide"[All Fields] AND "infant, premature"[MeSH Terms] OR ("infant"[All Fields] AND "premature"[All Fields]) OR "premature infant"[All Fields] OR "preterm"[All Fields] AND "infant"[All Fields] OR "preterm infant"[All Fields] OR "neonate"[All Fields]. The EMBASE and CINAHL searches used the following terms: ('premature infant'/exp. OR 'premature infant' OR (('premature'/exp. OR premature) AND ('infant'/exp. OR infant))) AND ('furosemide'/ exp. OR furosemide). The clinicaltrials.gov search used the terms "premature infant" and "furosemide."

We compiled all studies resulting from the preceding search strategy and removed duplicates. Two authors (WJ and GT) reviewed titles and abstracts for relevance using the software program Abstrackr [14]. We screened

\begin{tabular}{ll} 
Table 1 Eligibility Criteria & \\
\hline Patient/Population & $\begin{array}{l}\text { Infant }<37 \text { weeks completed } \\
\text { gestational age } \\
\geq 1 \text { dose of furosemide (IV or PO) } \\
\text { Iuring hospitalization in the neonatal } \\
\text { intensive care unit } \\
\text { Infant }<37 \text { weeks completed } \\
\text { gestational age without exposure } \\
\text { to furosemide } \\
\text { sensorineural hearing loss; } \\
\text { nephrocalcinosis/nephrolithiasis } \\
\text { Clinical trials, retrospective or } \\
\text { prospective cohort studies, } \\
\text { case-control studies }\end{array}$ \\
\hline
\end{tabular}


full text articles and developed data abstraction forms to determine eligibility of each study. If eligibility criteria were met, we recorded the study design, population characteristics, characteristics of comparison group, outcomes examined, sample size, duration of follow-up, and funding sources. These data abstraction forms were used by the investigators to report on the results (Additional file 1).

We assessed the quality (internal validity) of randomized controlled trials using the Cochrane Collaboration's tool for assessing risk of bias in clinical trials [15]. This tool includes the assessment of randomization procedures, allocation concealment, blinding of participants and investigators, completeness of outcomes data, selective reporting, and the risk of other biases. Each randomized controlled trial included in the systematic review was graded on each of these parameters as high risk of bias, low risk of bias, or unclear risk of bias. We assessed the risk of bias in non-randomized studies using the ROBINS-1 tool, which assesses confounding biases, bias in the selection of participants, classification biases, biases due to deviations from intended interventions, missing data biases, and biases in measurement of outcomes [16]. Bias is rated on a scale of low, moderate, serious, or critical risk of bias, or no information. We then graded the strength of the evidence for each key question using guidance from the Evidence-based Practice Center program of the U.S. Agency for Healthcare Research and Quality [17].

The pre-specified outcome measures were odds ratios and risk ratios, where appropriate, with 95\% confidence intervals for the exposure of furosemide in premature infants with each of the outcomes of interest addressed in the key questions. Results of each study were described and only the information pertaining to the outcomes of interest in the key questions were included.

\section{Results}

We identified 260 records through MEDLINE, 620 records through EMBASE, 51 records from CINAHL, and 1 study from clinicaltrials.gov. After removing duplicates, we screened 390 records for eligibility. We excluded 224 records due to study design, non-human population, or non-English language. We reviewed the full text of the remaining 166 articles and excluded 139 articles for inappropriate study population or lack of relevant safety outcome. We identified 5 articles in the reference lists of reviewed articles which met the eligibility criteria. These studies did not appear in the original search due to the use of a variation in the drug name: "frusemide", instead of "furosemide." In total, 32 articles were included in the quantitative analysis. See Fig. 1 for the PRISMA flow diagram.

\section{Key question 1: Does exposure to furosemide in premature infants increase the risk of sensorineural hearing loss?}

Only one randomized controlled trial of furosemide compared to placebo in premature infants reported on the outcome of SNHL [18]. In this trial, 24 premature infants were randomized to receive either furosemide or placebo for 7 days. The initial dose of furosemide $(1 \mathrm{mg} /$ $\mathrm{kg}$ IV or $2 \mathrm{mg} / \mathrm{kg}$ orally every $12 \mathrm{~h}$ ) was doubled after $48 \mathrm{~h}$ in infants where there was not a $50 \%$ increase in urine output over $12 \mathrm{~h}$. In the 17 infants available for analysis (7 infants in treatment group and 10 infants in the control group), no SNHL was detected prior to discharge.

We identified 11 observational studies examining the association of furosemide and SNHL in premature infants: 5 retrospective cohort studies and 6 case-control studies [19-29]. The results of the studies were mixed; however, an association between furosemide and SNHL was found in 8 of the 11 observational studies [19-23, 25, 27, 29]. Two cohort studies and one case-control study did not identify an association with furosemide and SNHL [24, 26, 28]. These negative studies were conducted in single centers and did not consider dose exposure of furosemide.

Table 2 summarizes the population characteristics, sample size, outcome measures, and results from each study. The studies varied considerably in their definitions of SNHL, including the type of auditory testing used and length of follow-up. However, every study included a hearing screen in all infants prior to NICU discharge and every infant classified as having SNHL failed the initial newborn hearing screen. Auditory testing in these studies included either auditory brain stem response (ABR) [19, 20, 22, 28], brainstem auditory evoked response (BAER) [21], otoacoustic emission (OAE) test [23], behavioral audiometry in older children, or some combination of these tests [24-27, 29]. Several studies differentiated auditory neuropathy or auditory neuropathy spectrum disorders, in which there is a defect in the transmission of sound from the inner hair cells of the cochlea to the brain via the auditory nerve, from the broader category of SNHL [25-27]. Infants with auditory neuropathy have an abnormal ABR with preserved OAE testing, while those with SNHL have abnormal results on both tests.

Although a majority of the studies did not consider dosing, three studies described the dose and duration of furosemide and its association with SNHL and each of these studies found a positive association between furosemide and SNHL [20, 22, 27]. One found higher cumulative dose exposure of furosemide in infants with hearing loss than was true in infants without hearing loss (mean +/- standard deviation: 139.1 +/- $130 \mathrm{mg} / \mathrm{kg}$ 
vs. $41.5+/-76 \mathrm{mg} / \mathrm{kg} ; p<0.001)$, in addition to longer duration of furosemide use in the hearing loss group $(52.5+/-43$ days vs. $19+/-23$ days; $p<0.001)$ [20]. In another study, investigators described higher maximum daily dose of furosemide $(3.2+/-0.58 \mathrm{mg} / \mathrm{kg}$ vs. 2.45 $+/-0.79 \mathrm{mg} / \mathrm{kg} ; p=0.05)$, longer duration of treatment $(17+/-8.3$ days vs. $3.4+/-2.1$ days; $p<0.001)$, and higher cumulative dose exposures $(26.9+/-13.7 \mathrm{mg} / \mathrm{kg}$ vs. $6.17+/-4 \mathrm{mg} / \mathrm{kg} ; \mathrm{p}<0.001)$ in infants with $\mathrm{SNHL}$ than in infants with normal hearing [22]. A third study reported a longer duration of furosemide treatment in infants with SNHL compared to those with normal hearing $(17.5+/-10$ days vs. $7+/-4.9$ days; $p=0.002)$ [27].

\section{Quality assessment}

We assessed the quality of each study based on the risk of bias in the seven domains of the ROBINS-I tool for non-randomized studies (Table 3). The risk of bias in the McCann study is included in Table 4 using the Cochrane Risk of Bias Tool. The primary determining factor for the assessment of moderate or serious risk of bias was whether an appropriate analysis method was used that controlled for important perinatal factors, such as severity of illness, duration of hospitalization, birth weight, gestational age, and co-morbidities known to be risk factors for hearing loss. We considered two studies to have a critical risk of bias due to grouping furosemide exposure with other medications as a single variable termed "ototoxins" $[19,29]$. There was no pattern relating quality to the results of the studies (i.e., both positive and negative studies included a mix of moderate and serious risks of bias).

\section{Strength of evidence}

We determined that the strength of evidence for the association of SNHL and furosemide exposure in premature infants is low based on our review of the existing

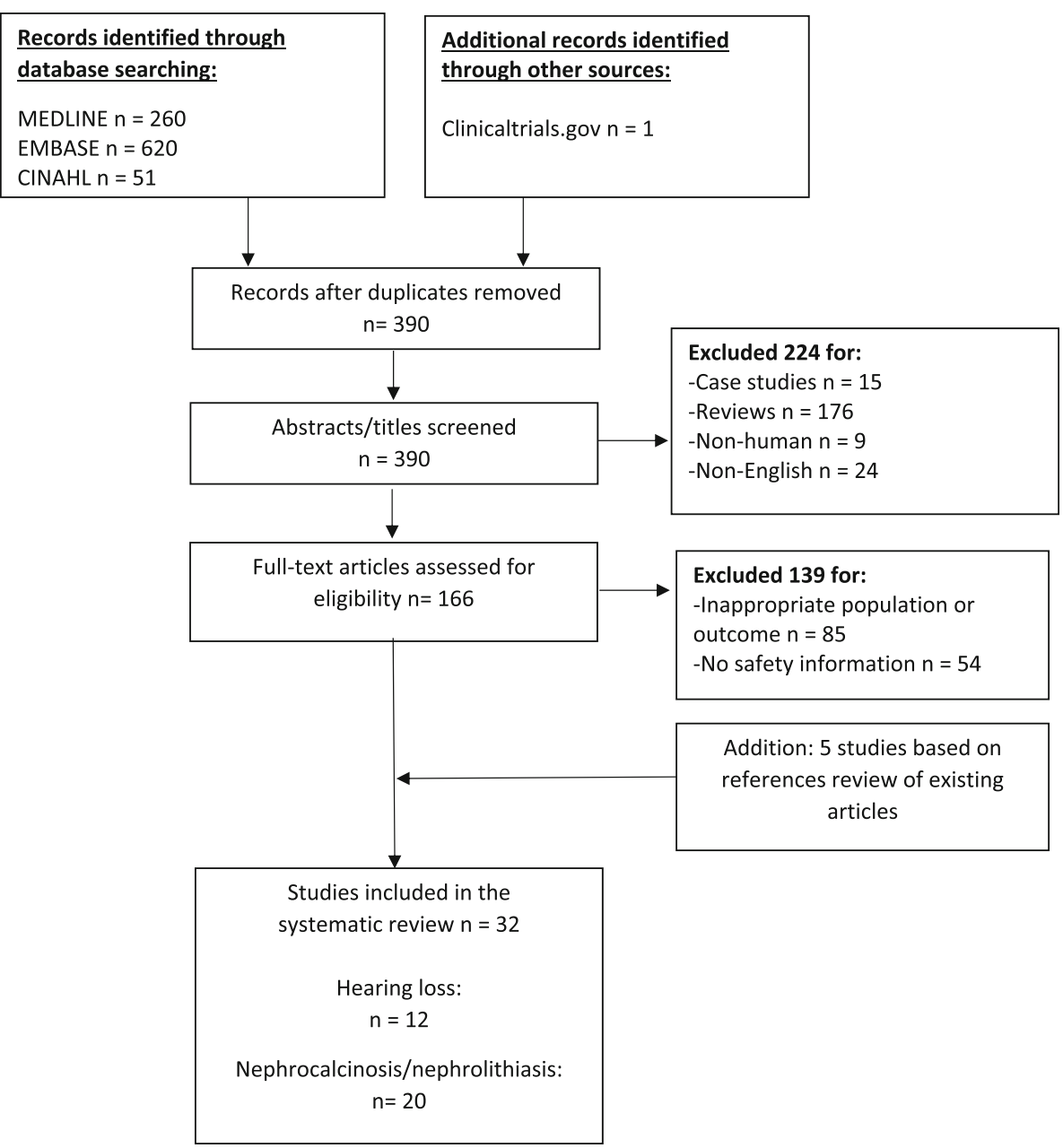

Fig. 1 PRISMA flow diagram for inclusion and exclusion of studies [71] 
Table 2 Summary of studies examining risk of hearing loss in premature infants

\begin{tabular}{|c|c|c|c|c|}
\hline Study (Year) & Design & Population and Sample Size & Outcome Measure & Results \\
\hline $\begin{array}{l}\text { Mjoen (1982) } \\
\text { [19] }\end{array}$ & cohort & $\begin{array}{l}60 \text { high-risk infants } \\
27-44 \text { weeks } G A\end{array}$ & $\begin{array}{l}\text { ABR testing in NICU } \\
\text { and follow-up visits }\end{array}$ & $\begin{array}{l}\text { - } 4 \text { infants with evidence of SNHL. } \\
\text { - } 3 / 4 \text { infants exposed to ototoxic } \\
\text { medications (furosemide and/or } \\
\text { aminoglycoside). }\end{array}$ \\
\hline $\begin{array}{l}\text { McCann (1985) } \\
{[18]}\end{array}$ & $\begin{array}{l}\text { randomized } \\
\text { controlled }\end{array}$ & $\begin{array}{l}17 \text { premature infants with } \\
\text { BPD ( } 7 \text { infants received } \\
\text { furosemide and } 10 \text { infants } \\
\text { received placebo) }\end{array}$ & $\begin{array}{l}\text { Audiology screen at } \\
\text { discharge and } \\
\text { follow-up visits }\end{array}$ & - Normal hearing in all infants. \\
\hline $\begin{array}{l}\text { Salamy (1989) } \\
{[20]}\end{array}$ & cohort & GA 24-34 weeks & $\begin{array}{l}\text { ABR in NICU and follow-up; } \\
\text { behavioral audiometry from } \\
3 \text { months to } 4 \text { years }\end{array}$ & $\begin{array}{l}\text { - Infants with SNHL received greater } \\
\text { amounts of furosemide for longer } \\
\text { durations, in combination with } \\
\text { aminoglycoside or vancomycin } \\
\text { therapy ( } p<0.001 \text { for all factors). }\end{array}$ \\
\hline $\begin{array}{l}\text { Brown (1991) } \\
\text { [21] }\end{array}$ & case-control & $\begin{array}{l}35 \text { infants with SNHL and } \\
70 \text { matched hearing-intact } \\
\text { controls }\end{array}$ & $\begin{array}{l}\text { BAER testing prior to } \\
\text { discharge from NICU }\end{array}$ & $\begin{array}{l}\cdot 17 / 35(49 \%) \text { infants with SNHL } \\
\text { and } 6 / 70(9 \%) \text { controls were } \\
\text { exposed to furosemide }(p<0.0001) \text {. }\end{array}$ \\
\hline $\begin{array}{l}\text { Borradori (1997) } \\
{[22]}\end{array}$ & case-control & $\begin{array}{l}8 \text { children with progressive bilateral } \\
\text { deafness born preterm (GA } \leq 34 \text { weeks) } \\
\text { with } 16 \text { controls matched on GA and BW } \\
\text { and } 15 \text { controls matched on perinatal } \\
\text { complications }\end{array}$ & $\begin{array}{l}\text { ABR at NICU discharge } \\
\text { and follow-up }\end{array}$ & $\begin{array}{l}\text { - } 8 / 8(100 \%) \text { infants with } \mathrm{SNHL} \text { and } \\
13 / 15(87 \%) \text { controls received } \\
\text { furosemide (NS). } \\
\text { - Mean duration }(p<0.001) \text {, total } \\
\text { cumulative dose }(p<0.001) \text {, and } \\
\text { maximum daily dose }(p=0.05) \\
\text { were higher in SNHL group. }\end{array}$ \\
\hline Ertl (2001) [23] & case-control & $\begin{array}{l}22 \text { premature infants with } \mathrm{SNHL} \text { and } 25 \\
\text { controls matched on GA, BW, and perinatal } \\
\text { factors associated with hearing loss }\end{array}$ & $\begin{array}{l}\text { OAE test and } A B R \text { if failed } \\
\text { OAE }\end{array}$ & $\begin{array}{l}\text { - } 4 / 22(18 \%) \text { infants with SNHL } \\
\text { and } 1 / 25(4 \%) \text { controls received } \\
\text { furosemide }(p<0.01) \text {. }\end{array}$ \\
\hline $\begin{array}{l}\text { Rais-Bahrami } \\
\text { (2004) [24] }\end{array}$ & cohort & $\begin{array}{l}57 \text { infants who received furosemide } \\
\text { and } 207 \text { infants who did not receive } \\
\text { furosemide }\end{array}$ & $\begin{array}{l}\mathrm{OAE}, \mathrm{ABR} \text {, or both } \\
\text { prior to NICU discharge }\end{array}$ & $\begin{array}{l}\text { - No difference in abnormal hearing } \\
\text { screen in furosemide and non- } \\
\text { furosemide groups ( } 16 \% \text { vs. } 16 \% \text {; } \\
p=0.95 \text { ). }\end{array}$ \\
\hline $\begin{array}{l}\text { Xoinis (2007) } \\
{[25]}\end{array}$ & case-control & $\begin{array}{l}71 \text { infants with } \mathrm{SNHL}, 24 \text { with auditory } \\
\text { neuropathy, and } 95 \text { controls matched } \\
\text { on GA, BW, and birth year }\end{array}$ & $\mathrm{ABR}$ and $\mathrm{OAE}$ & $\begin{array}{l}\text { - Higher exposure to furosemide } \\
\text { in SNHL group }(51 \%) \text { and AN } \\
\text { group }(96 \%) \text { compared to } \\
\text { control group }(32.6 \%)(p<0.05) \\
\text { for both comparisons. }\end{array}$ \\
\hline $\begin{array}{l}\text { Coenraad (2011) } \\
{[26]}\end{array}$ & case-control & $\begin{array}{l}9 \text { infants with hearing loss and } 36 \text { controls } \\
\text { matched on GA, gender, and birth year }\end{array}$ & $\begin{array}{l}\text { ABR screening prior to NICU } \\
\text { discharge and repeat ABR and } \\
\text { OAE at follow-up visit for } \\
\text { failed screening. }\end{array}$ & $\begin{array}{l}\text { - No differences in furosemide } \\
\text { exposure between groups } \\
\text { ( } 44 \% \text { vs. } 25 \% ; p=0.56)\end{array}$ \\
\hline $\begin{array}{l}\text { Martinez-Cruz } \\
(2012)[27]\end{array}$ & case-control & $\begin{array}{l}6 \text { children with SNHL and } 87 \\
\text { normal-hearing controls with } \\
\text { birth weights }<750 \mathrm{~g}\end{array}$ & $\begin{array}{l}\text { BAER screening and OAE at } \\
\text { follow-up visits for failed } \\
\text { initial screening }\end{array}$ & $\begin{array}{l}\text { - } 6 / 6(100 \%) \text { infants with } \mathrm{SNHL} \\
\text { and } 45 / 87(52 \%) \text { control infants } \\
\text { received furosemide }(p=0.002) \text {. } \\
\text { - Longer average duration of } \\
\text { furosemide in SNHL infants who } \\
\text { received furosemide compared } \\
\text { with controls ( } 18 \text { days vs. } 7 \text { days). }\end{array}$ \\
\hline $\begin{array}{l}\text { Rastogi (2013) } \\
{[28]}\end{array}$ & cohort & Infants with BW < $1500 \mathrm{~g}$. & $\begin{array}{l}\text { ABR prior to NICU discharge; } \\
\text { Follow-up at } 2 \text { years for failed } \\
\text { screening to determine } \\
\text { hearing status }\end{array}$ & $\begin{array}{l}\text { - No association with furosemide } \\
\text { and hearing loss when adjusting } \\
\text { for BW, GA, and other perinatal } \\
\text { risk factors (OR 1.18; } p=0.3 \text { ). }\end{array}$ \\
\hline $\begin{array}{l}\text { Wang (2017) } \\
\text { [29] }\end{array}$ & cohort & $\begin{array}{l}\text { Included all infants with BW } \leq 1500 \text { g. } 297 \\
\text { infants with normal hearing and } 12 \text { infants } \\
\text { with hearing loss }\end{array}$ & $\begin{array}{l}\text { OAE before discharge and } \\
\text { BAER at } 3 \text { months corrected } \\
\text { age if failed initial screen }\end{array}$ & $\begin{array}{l}\text { - Exposure to ototoxins (furosemide } \\
\text { and/or gentamicin) was associated } \\
\text { with hearing loss (OR 3.62; } 95 \% \\
\text { Cl 1.67-7.82). }\end{array}$ \\
\hline
\end{tabular}


Table 3 Quality assessment of observational studies examining risk of hearing loss in premature infants

\begin{tabular}{ll}
\hline Study (Year) & $\begin{array}{l}\text { Risk of Bias } \\
\text { Serious, Crit }\end{array}$ \\
\hline Mjoen (1982) [19] & Critical \\
Salamy (1989) [20] & Moderate \\
Brown (1991) [21] & Serious \\
Borradori (1997) [22] & \\
Ertl (2001) [23] & Moderate \\
Rais-Bahrami (2004) [24] & Serious \\
Xoinis (2007) [25] & Serious \\
Coenraad (2011) [26] & Serious \\
Martinez-Cruz (2012) [27] & Serious \\
Rastogi (2013) [28] & Moderate \\
Wang (2017) [29] & Critical
\end{tabular}

Critical risk of bias in classification of interventions domain: ototoxic medications grouped as one variable (i.e., furosemide not identified as a single risk factor).

Confounding well-accounted for by assessing "neonatal status" based on duration of hospitalization, days of assisted ventilation, radiography and lab results, etc.

Serious risk of bias in confounding domain: Selection of variables included in the multivariate analyses based solely on results of univariate analyses and did not adequately account for severity of illness in each group.

Confounding well-accounted for by the creation of two control groups based on BW/GA and perinatal complications related to risk of ototoxicity.

Serious risk of bias in confounding domain: infants not matched on severity of illness or co-morbidities associated with hearing loss.

Serious risk of bias in confounding domain: no adjustment for perinatal factors related to hearing loss.

Serious risk of bias in confounding domain: infants not matched on severity of illness or co-morbidities associated with hearing loss.

Serious risk of bias in confounding domain: infants not matched on severity of illness or co-morbidities associated with hearing loss.

Serious risk of bias in confounding domain: infants not matched on severity of illness or co-morbidities associated with hearing loss.

Confounding well-accounted for in multivariate analyses, which adjusted for GA, BW, and other known perinatal risk factors for hearing loss.

Critical risk of bias in classification of interventions domain: ototoxic medications grouped as one variable (i.e., furosemide not identified as a single risk factor).

Legend: $B W$ Birth weight, GA Gestational age

literature. This judgement is based on the high risk of bias in the observational studies, which often did not adequately account for the severity of illness in infants exposed to furosemide, and the inconsistency in the results. Furthermore, there is a problem with the directness of comparisons as infants exposed to furosemide are also more likely to receive additional interventions which may increase the risk of SNHL, such as concomitant ototoxic medications and mechanical ventilation. According to the Agency for Healthcare Research and Quality (AHRQ), a low grade indicates "low confidence that the evidence reflects the true effect [and] further research is likely to change the confidence in the estimate of effect and is likely to change the estimate" [17]. It is clear that further clinical trials are needed to adequately assess the risk of SNHL in premature infants exposed to furosemide.

\section{Key question 2: Does exposure to furosemide in} premature infants increase the risk of nephrocalcinosis/ nephrolithiasis?

No randomized controlled trials of furosemide in premature infants have been performed that include outcome data on the incidence of $\mathrm{NC} / \mathrm{NL}$. We identified 20 cohort studies examining the association of furosemide exposure and NC/NL [30-49]. The results of the studies were mixed; however, 12 of the 20 studies found an association between furosemide and NC/NL [30-32, 34-37, 40, 41, 44, 46, 47, 49]. All studies were performed at single centers, except one, which included infants from two centers [40]. Three of the studies resembled case series in that there was no inclusion of adequate control groups without NC: one of these studies found an association of furosemide with NC and two studies did not [30, 38, 42].

Table 4 Risk of bias in trials examining risk of hearing loss in premature infants

\begin{tabular}{|c|c|c|c|c|c|c|c|}
\hline \multirow[t]{2}{*}{ Study (Year) } & \multicolumn{7}{|c|}{ Risk of Bias (High, Low, Unclear) } \\
\hline & $\begin{array}{l}\text { Random Sequence } \\
\text { Generation }\end{array}$ & $\begin{array}{l}\text { Allocation } \\
\text { Concealment }\end{array}$ & $\begin{array}{l}\text { Blinding of Participants } \\
\text { and Personnel }\end{array}$ & $\begin{array}{l}\text { Blinding of Outcome } \\
\text { Assessment }\end{array}$ & $\begin{array}{l}\text { Incomplete } \\
\text { Outcome Data }\end{array}$ & $\begin{array}{l}\text { Selective } \\
\text { Reporting }\end{array}$ & $\begin{array}{l}\text { Other } \\
\text { Bias }\end{array}$ \\
\hline McCann (1985) [18] & Low & Low & Low & Low & High & Unclear & Low \\
\hline
\end{tabular}


Table 5 summarizes the population characteristics, sample size, outcome measures, and results from each study. There was considerable variability in the inclusion criteria, the timing of renal ultrasonography, and duration of long-term follow-up. However, all of the reviewed studies included premature infants with sonographic evidence of $\mathrm{NC} / \mathrm{NL}$ prior to discharge from the NICU. Of the studies that included subsequent ultrasounds after NICU discharge, complete resolution of NC occurred in $44-100 \%$ of infants by 2 years of age [31, 33, 35, 36, 38, 39, 42, 46-49]. However, these data on outcomes are incomplete, as they do not include infants with the most severe disease, who expired during their NICU hospitalization, and infants lost to follow-up after discharge.

A dose-response relationship between furosemide and $\mathrm{NC} / \mathrm{NL}$ was evaluated in 8 studies [33, 34, 38, $39,41,42,44,46]$. Half of these studies found no association between dose and the development of $\mathrm{NC} /$ NL. Two studies found no difference in average daily dose or duration of furosemide between infants with $\mathrm{NC}$ and infants without $\mathrm{NC}[33,34]$. Investigators reported no difference in cumulative dose or duration of treatment between infants with resolution of $\mathrm{NC}$ compared to those with persistent findings of $\mathrm{NC}$ [38]. An additional study found no difference in median total dose of furosemide before detection of $\mathrm{NC}$ and in those infants without NC in another study [41]. In contrast, one study found that infants with resolution of $\mathrm{NC}$ received lower daily dosages of furosemide than did those with persistent NC $(p<0.05)$ and another determined that mean cumulative doses of furosemide were significantly higher in infants with NC than in those without NC (18.8 mg vs $5.0 \mathrm{mg}$; p: 0.001) $[39,42]$. A single center study found higher cumulative doses of furosemide in infants with development of $\mathrm{NC}$ than in those without NC (mean $+/-$ standard deviation: $102.2+/-118.2 \mathrm{mg}$ vs $32.3+/-81.1 \mathrm{mg} ; p=0.001$ ) [44]. Investigators identified exposure to furosemide with cumulative dose $>10 \mathrm{mg} / \mathrm{kg}$ was the strongest independent risk factor for $\mathrm{NC}$ in a multivariable analysis of premature infants (OR 48.1 (95\% CI 4.0-585); $p<0.01)$ [46].

\section{Quality assessment}

We assessed the quality of each study based on the risk of bias in the seven domains of the ROBINS-I tool for non-randomized studies (Table 6). We determined that one study had a critical risk of bias and resembled a case series in its lack of the use of a control group [30]. The most common reason we considered a study to have a serious risk of bias was the absence of adjustment for severity of illness. Three studies used multivariable analysis to control for the high correlation of cumulative furosemide exposure with birthweight, duration of mechanical ventilation, and severity of $\mathrm{BPD}$, all variables that are independently associated with the development of NC/NL $[34,41,46]$. One study found that furosemide exposure was the strongest independent risk factor for NC, despite controlling for multiple markers of illness severity. However, two studies that considered the temporal relationship between furosemide and $\mathrm{NC}$ found no difference in mean dose of furosemide before detection of NC on renal ultrasound in infants who did or did not subsequently develop NC [34, 41]. There was no pattern relating quality to the results of the studies (i.e., both positive and negative studies included a mix of moderate and serious risks of bias).

\section{Strength of evidence}

We determined that the strength of evidence for the association of $\mathrm{NC} / \mathrm{NL}$ and furosemide exposure in premature infants is low based on our review of the existing literature. No clinical trials of furosemide have examined the outcome of $\mathrm{NC} / \mathrm{NL}$. There is a high risk of bias in the numerous observational studies reviewed as only a few studies accounted for other renal stone-promoting factors, such as concomitant medication use and supplementation of calcium, phosphorus, and vitamin D to reduce the risk of osteopenia of prematurity. The AHRQ classifies evidence as indirect if "it uses intermediate or surrogate outcomes instead of ultimate health outcomes; one body of evidence links the intervention to intermediate outcomes and another body of evidence links the intermediate to most important (health or ultimate) outcomes." (p. 515) The endpoint of NC/NL is likely a surrogate outcome for chronic kidney disease and cardiovascular disease, which were detected in a minority of infants included in the studies. Although clinical trials are needed to determine the relationship of furosemide and $\mathrm{NC} / \mathrm{NL}$, adequate long-term follow-up will also be required to determine any lasting effects of $\mathrm{NC} / \mathrm{NL}$ on renal and cardiovascular health.

\section{Discussion}

We found no evidence that furosemide exposure increases the risk of SNHL or $\mathrm{NC} / \mathrm{NL}$ in premature infants. We determined that the strength of evidence for the association of these outcomes with furosemide exposure is low. With the exception of one randomized controlled trial including SNHL as an outcome, all reviewed studies were cohort or case-control studies. These studies' observational designs left many important potential confounding variables not well-accounted for, such as severity of illness, duration of mechanical ventilation, and concomitant medication exposures. Some of the included cohort studies were of high quality and used multivariable analyses to account for confounding, but randomized controlled trials of furosemide are 
Table 5 Summary of studies examining risk of nephrocalcinosis/nephrolithiasis (NC/NL) in premature infants

\begin{tabular}{|c|c|c|c|}
\hline Study (Year) & Design & Population and Sample Size & Outcome Measure \\
\hline Hufnagle (1982) [30] & cohort & 10 premature infants with NC & $\begin{array}{l}\text { RUS during NICU } \\
\text { admission }\end{array}$ \\
\hline Woolfield (1988) [31] & cohort & 36 infants with $\mathrm{BW} \leq 1500 \mathrm{~g}$ & RUS at 12 months of age \\
\hline Jacinto (1988) [32] & cohort & 31 infants with $B W<1500 \mathrm{~g}$ & $\begin{array}{l}\text { RUS in third week of life } \\
\text { and every } 3 \text { week } \\
\text { thereafter until NICU } \\
\text { discharge }\end{array}$ \\
\hline Ezzedeen (1988) [33] & cohort & $\begin{array}{l}17 \text { premature infants with NC treated with } \\
\text { furosemide; } 3 \text { premature infants treated with } \\
\text { furosemide without NC (control group) }\end{array}$ & $\begin{array}{l}\text { RUS during NICU } \\
\text { admission }\end{array}$ \\
\hline Short (1991) [34] & cohort & 79 infants with $\mathrm{GA}<32$ weeks & Serial RUS \\
\hline
\end{tabular}

Downing (1991) [35] cohort 117 infants with BW < $1750 \mathrm{~g}$ and BPD treated with furosemide

Downing (1992) [36] cohort 27 infants with BW $<1500$ g enrolled into 3 groups: 1) not exposed to furosemide $(n=7)$; 2) received furosemide without NC $(n=10)$; and 3$)$ received furosemide with NC $(n=10)$

Stafstrom (1992) [37] cohort 11 premature infants with post-hemorrhagic hydrocephalus treated with furosemide and acetazolamide

Pope (1996) [38]

cohort 13 premature infants with NC and exposed to furosemide divided into 2 groups: resolution of $\mathrm{NC}(n=6)$ and persistent NC $(n=7)$

Saarela (1999) [39]

cohort 129 infants with $\mathrm{BW}<1500 \mathrm{~g}$

Schell-Feith (2000) [40] cohort 215 infants with GA $<32$ weeks

Narendra (2001) [41] cohort 101 infants with $G A<32$ weeks or $\mathrm{BW}<1500 \mathrm{~g}$

Hoppe (2002) [42]

cohort 16 infants with $\mathrm{GA}<37$ weeks and diagnosed with $\mathrm{NC}$
RUS and laboratory testing for glomerular and tubular kidney function

Serial RUS

Serial RUS in 3-6 month intervals for positive findings of $\mathrm{NC} / \mathrm{NL}$

RUS at 2 weeks, 6 weeks, and 3 months of life

RUS at 4 weeks of life and at term

RUS at 1 month of age and at term or NICU discharge

RUS during NICU admission and every 3-6 months following discharge
- All infants received furosemide

of at least $2 \mathrm{mg} / \mathrm{kg} /$ day for at least 12 days prior to NC.

- 3/32 (9\%) infants had NC on RUS and had received chronic furosemide with doses ranging from 2 to $8 \mathrm{mg} / \mathrm{kg} /$ day.

- $N C$ resolved in 2/3 (67\%) cases; 1 died of unrelated causes.

- NC was diagnosed in 20/31 (64\%) of infants.

- Exposure to furosemide was more common in NC group (65\% vs $9 \%$; $p<0.001)$.

- No difference in average daily dose or duration of furosemide in NC group compared to control group.

-21/79 (27\%) of infants diagnosed with NC.

- No difference in mean total dose of furosemide.

-20/117 (17\%) had evidence of NC/NL on RUS prior to discharge.

- Infants maintained on furosemide were more likely to have persistent $\mathrm{NC} / \mathrm{NL}$ compared to those for whom furosemide was stopped $(p<0.001)$.

- Infants in group 3 had lower creatinine clearance (reduced glomerular function) and higher tubular dysfunction compared to infants in group 1 and 2.

- 5/11 (45\%) infants with evidence of NC - No correlation between duration of treatment, total dosage of medications, and development of renal calculi.

- No difference in duration of or cumulative dose of furosemide in infants with resolution of $\mathrm{NC}$ compared to those with persistence of NC.

- 26/129 (20\%) of infants diagnosed with NC.

- The mean cumulative doses of furosemide were significantly higher in infants with NC compared to those without NC (19 mg vs 5 mg; $p<0.001$ ).

- NC diagnosed in 50/150 (33\%) of infants at 4 weeks of life and 83/201 (41\%) at term (NS).

- At term, furosemide exposure was higher in those with NC (32\%) compared to those without NC $(18 \%)(p<0.001)$.

. 16/101 (16\%) diagnosed with NC. - The median total dose of furosemide was not significantly different before detection of NC on term RUS and in infants without NC ( $p=0.75)$.

- NC persisted in 4/12 (33\%) infants who received follow-up.

- Infants with resolution of NC received

lower dosages of furosemide compared to those with persistent NC $(p<0.05)$. 
Table 5 Summary of studies examining risk of nephrocalcinosis/nephrolithiasis (NC/NL) in premature infants (Continued)

\begin{tabular}{|c|c|c|c|c|}
\hline Study (Year) & Design & Population and Sample Size & Outcome Measure & Results Summary \\
\hline Hein (2004) [43] & cohort & $\begin{array}{l}114 \text { infants with BW }<1500 \mathrm{~g} \text { divided into } 2 \\
\text { groups: 1) NC }(n=20) ; 2) \text { without NC ( } n=94) \text {. } \\
20 \text { infants from control group matched to NC } \\
\text { group based on BW and GA. }\end{array}$ & $\begin{array}{l}\text { RUS every } 2 \text { weeks } \\
\text { during NICU admission }\end{array}$ & $\begin{array}{l}\text { - No difference in duration of furosemide } \\
\text { therapy between groups. }\end{array}$ \\
\hline Ketkeaw (2004) [44] & cohort & $\begin{array}{l}36 \text { infants with } \mathrm{GA}<32 \text { weeks and } \\
\mathrm{BW}<1250 \mathrm{~g}\end{array}$ & $\begin{array}{l}\text { RUS prior to NICU } \\
\text { discharge }\end{array}$ & $\begin{array}{l}\text { - } 14 / 36(39 \%) \text { were diagnosed with NC. } \\
\text { - The mean cumulative dose and mean } \\
\text { duration of furosemide was higher in } \\
\text { infants with NC compared to those } \\
\text { without NC ( } 102 \text { mg vs } 32 \text { mg; } \\
p=0.001 \text { and } 39 \text { vs } 7 \text { days; } p=0.001 \text { ). }\end{array}$ \\
\hline Cranefield (2004) [45] & cohort & $\begin{array}{l}\text { Cohort of infants enrolled in randomized trial } \\
\text { of two regimens of dexamethasone for the } \\
\text { prevention of BPD. }\end{array}$ & $\begin{array}{l}\text { RUS on study entry, day of } \\
\text { life } 28 \text {, and at discharge or } \\
36 \text { weeks postmenstrual age }\end{array}$ & $\begin{array}{l}\text { - } 15 / 18(83 \%) \text { of infants for whom } \\
\text { complete data were available were } \\
\text { diagnosed with NC prior to discharge } \\
\text { or } 36 \text { weeks postmenstrual age. } \\
\text { - Furosemide was used infrequently in } \\
\text { the trial. } 7 / 8 \text { ( } 88 \% \text { ) of the infants who } \\
\text { never received furosemide } \\
\text { developed NC. }\end{array}$ \\
\hline Gimpel (2010) [46] & cohort & $\begin{array}{l}55 \text { infants with } \mathrm{GA}<32 \text { weeks and } \\
\mathrm{BW}<1500 \mathrm{~g}\end{array}$ & $\begin{array}{l}\text { RUS obtained after the } \\
\text { first month of life }\end{array}$ & $\begin{array}{l}\text { - } 15 / 55(27 \%) \text { of infants were } \\
\text { diagnosed with NC. } \\
\text { - The strongest independent risk factor } \\
\text { for NC was furosemide therapy with } \\
\text { cumulative dose }>10 \mathrm{mg} / \mathrm{kg} \text { (OR } 48.1 \\
(95 \% \mathrm{Cl} 4.0-585) ; p<0.01) \text {. }\end{array}$ \\
\hline Chang (2011) [47] & cohort & $\begin{array}{l}102 \text { infants with } \mathrm{GA}<34 \text { weeks and } \mathrm{BW}< \\
1500 \mathrm{~g}\end{array}$ & $\begin{array}{l}\text { RUS at term or prior to NICU } \\
\text { discharge }\end{array}$ & $\begin{array}{l}-6 / 102(6 \%) \text { of infants were diagnosed } \\
\text { with NC. } \\
\text { - Exposure to furosemide was more } \\
\text { common in the NC group compared } \\
\text { to the group without NC ( } 33 \% \text { vs } 3 \% \text {; } \\
p=0.027 \text { ). }\end{array}$ \\
\hline Lee (2014) [48] & cohort & 52 infants with $B W<1500 \mathrm{~g}$ & RUS at 4 and 8 weeks of life & $\begin{array}{l}\text { - Exposure to furosemide did not differ } \\
\text { significantly between infants with NC } \\
\text { and those without NC. }\end{array}$ \\
\hline Mohamed (2014) [49] & cohort & 97 infants with GA $\leq 34$ weeks & $\begin{array}{l}\text { RUS at first week of life, } \\
\text { at term, and at one year } \\
\text { corrected age }\end{array}$ & $\begin{array}{l}\text { - Exposure to furosemide was more } \\
\text { common in the NC group compared } \\
\text { to the group without NC ( } 50 \% \text { vs } 16 \% \text {; } \\
p=0.003 \text { ). }\end{array}$ \\
\hline
\end{tabular}

Legend: $B W$ Birth weight, GA Gestational age, OR Odds ratio, $C$ Confidence interval, BPD Bronchopulmonary dysplasia

urgently needed to assess the risks of SNHL and NC/NL in premature infants.

Despite the proposed benefits and biological plausibility of using furosemide to improve respiratory outcomes, the efficacy of furosemide in premature infants has not been established. A Cochrane systematic review examining loop diuretics for preterm infants found no evidence to support an improvement in long-term outcomes, including BPD [50]. However, results from the review indicated that chronic administration of furosemide (i.e., at least 7 days) improves oxygenation and lung compliance in premature infants with established BPD. The review emphasizes the need for randomized clinical trials to assess the effects of furosemide administration on morbidity and mortality.

Notwithstanding the absence of data supporting the efficacy of furosemide, the medication is commonly used by clinicians in the neonatal intensive care unit (NICU) with the intention to improve oxygenation and wean respiratory support in premature infants. A cohort study from more than 300 NICUs in the U.S. found that furosemide was the fifth most common drug used between the years 2005 to 2010 in premature infants with birth weights $<1000 \mathrm{~g}$, with approximately $50 \%$ of these infants exposed to at least one dose of furosemide during their initial hospitalization [51]. Although other diuretic medications are used in the NICU for similar indications, furosemide is by far the most commonly used diuretic in the NICU, accounting for $93 \%$ of diuretic use [52]. Furosemide is also variably used in the NICU setting. A cohort study of infants with birth weights $<1500 \mathrm{~g}$ from more than 200 U.S. NICUs over a 15 year period found considerable variability in the percentage of infants exposed to at least one dose of furosemide at each particular site, with a median exposure by site of $33 \%$ and a range of 0 to $75 \%$. The observations from this study emphasize the lack of a universally accepted standard governing when to expose an infant in the NICU to furosemide and indicate that at some centers, no exposure to furosemide is an option [52].

Additional potential adverse outcomes of furosemide use in premature infants include metabolic bone disease 
(osteopenia) of prematurity and electrolyte abnormalities related to urinary loss of sodium, chloride, and calcium [53-55]. As with other adverse outcomes, the etiology of metabolic bone disease in premature infants likely has many causes, and infants with severe illness often have multiple risk factors such as insufficient phosphorus intake, vitamin D deficiency, prolonged immobilization, mechanical ventilation, and exposure to steroids and antibiotics [56-58]. However, there is a lack of consensus on the definition of metabolic bone disease of prematurity, with some definitions relying on serum mineral levels and others based on radiographical findings [59]. As a result, this review did not focus on metabolic bone disease of prematurity as an outcome of interest in premature infants exposed to furosemide.

Existing safety data on the use of furosemide in adults and children cannot be extrapolated to premature infants due to higher extracellular fluid volume per unit body weight, immature hepatic and renal function, and a more permeable blood-brain barrier in premature infants, variables which can alter the rates of drug absorption, distribution, metabolism, and elimination [60]. Four studies of furosemide pharmacokinetics in premature infants demonstrate significant variability in the volume of distribution, clearance, and half-life of the drug based on gestational age at birth, birth weight, and

Table 6 Quality assessment of observational studies examining risk of nephrocalcinosis/nephrolithiasis (NC/NL) in premature infants

\begin{tabular}{ll}
\hline Study (Year) & $\begin{array}{l}\text { Risk of Bias } \\
\text { Serious, Cr }\end{array}$ \\
\hline Hufnagle (1982) [30] & Critical \\
Woolfield (1988) [31] & Serious \\
Jacinto (1988) [32] & Serious \\
Ezzedeen (1988) [33] & Serious \\
Short (1991) [34] & Moderate \\
Downing (1991) [35] & Moderate \\
Downing (1992) [36] & Moderate \\
Stafstrom (1992) [37] & Serious
\end{tabular}
Comments

Critical risk of bias in confounding domain: no statistical tests performed in the analysis to test association of NC and furosemide. Critical risk of bias in selection of participants into the study: All infants were exposed to furosemide and had NC; lack of control group.

Serious risk of bias in confounding domain: no statistical tests performed in the analysis to test association of NC and furosemide.

Serious risk of bias in confounding domain: Lower BW and GA associated with outcome (NC), along with exposure to furosemide. Did not control for severity of illness.

Serious risk of bias in confounding domain: no adjustment for severity of illness; small number of infants in control group.

Multivariate analyses controlling for other risk factors for NC. Dose-response relationship evaluated.

All infants screened for the outcome had a diagnosis of chronic lung disease; high percentage of follow-up imaging obtained.

Robust comparators; long-term follow-up.

Serious risk of bias in confounding domain: no statistical tests performed in the analysis to test association of NC and furosemide. No reporting of frequency of NC in infants with post-hemorrhagic hydrocephalus not exposed to furosemide.

$\begin{array}{ll}\text { Pope (1996) [38] } & \text { Moderate } \\ \text { Saarela (1999) [39] } & \text { Moderate } \\ \text { Schell-Feith (2000) [40] } & \text { Moderate } \\ \text { Narendra (2001) [41] } & \text { Moderate } \\ \text { Hoppe (2002) [42] } & \text { Serious } \\ \text { Hein (2004) [43] } & \text { Moderate } \\ \text { Ketkeaw (2004) [44] } & \text { Moderate } \\ \text { Cranefield (2004) [45] } & \text { Moderate } \\ \text { Gimpel (2010) [46] } & \text { Moderate } \\ \text { Chang (2011) [47] } & \text { Serious } \\ \text { Lee (2014) [48] } & \text { Serious } \\ \text { Mohamed (2014) [49] } & \text { Serious }\end{array}$

Similar severity of illness in each group; long-term follow up with serial ultrasounds. Dose-response relationship evaluated.

Dose-response relationship evaluated.

Large sample size. Control group without NC included.

Multivariate analyses controlling for other risk factors for NC. Dose-response relationship evaluated.

Serious risk of bias in confounding domain: Lack of control group without NC.

Large sample size with appropriate control groups.

Appropriate control group included. Dose-response relationship evaluated.

All infants with comparable severity of illness.

Multivariate analyses controlling for other risk factors for NC. Dose-response relationship evaluated.

Serious risk of bias in confounding domain: no adjustment for severity of illness. Low incidence of NC in sample.

Serious risk of bias in confounding domain: no adjustment for severity of illness. Serious risk of bias in confounding domain: no adjustment for severity of illness. 
postnatal age [61-64]. The limited available data on pharmacokinetics and safety have led to a growing recognition of the need for clinical trials in premature infants to determine the safety and efficacy of therapeutic agents, such as furosemide $[65,66]$.

A phase II clinical trial by the Pediatric Trials Network is underway to better understand the safety of furosemide in premature infants at risk of BPD [67]. This trial will enroll premature infants born $<29$ weeks' gestation and receiving positive airway pressure or mechanical ventilation on 7-28 days postnatal age. The study design includes a dose escalation schedule with three cohorts randomized to placebo or furosemide. Primary outcomes will include safety information on SNHL (based on BAER prior to discharge) and NC/NL determined by serial renal ultrasounds. Secondary outcomes will assess effectiveness of early furosemide in the prevention of BPD or death. The dose escalation design of the study will allow for evaluation of a dose-response relationship of furosemide and the outcomes of SNHL and NC.

Premature infants, particularly those born small for gestational age, are at an increased risk for cardiovascular and renal disease in later life, likely due to a combination of genetic and environmental factors [68]. It is important to understand whether furosemide exposure, with or without evidence of $\mathrm{NC} / \mathrm{NL}$, contributes to the development of chronic kidney disease in these infants. Future studies investigating the safety of furosemide in premature infants will need to consider long-term surveillance of renal disease, particularly in those who develop NC/NL. The study design of trials investigating furosemide in the neonatal population should incorporate serial renal sonography, blood pressure measurements, urinalysis for proteinuria, and serum creatinine, where appropriate, to determine renal function over time.

This systematic review was limited by the inclusion of only one randomized controlled trial. The remaining studies were cohort and case-control studies, which by the nature of their study design are unable to demonstrate a causal role. While many randomized controlled trials of furosemide in premature infants have been performed, very few included data on safety outcomes, which were the subject of this review. In addition, the search strategy was limited to studies published in English may not have included all available studies; for instance, we found that some studies included from our review of reference lists used variable spellings of "furosemide." The field of neonatology has changed dramatically over the past 20 years with the introduction of antenatal steroids, surfactant replacement therapy, and non-invasive ventilation strategies. These practices have resulted in significantly improved survival and reduced morbidities in premature infants [69, 70]. Therefore, results from studies included in this review which were performed decades ago may not be applicable to infants born in the current era. Finally, we were unable to perform a meta-analysis of the included observational studies due to a lack of uniformity in outcome definitions, population characteristics, and length of follow-up.

\section{Conclusions}

This systematic review of the safety of furosemide in premature infants focuses on the outcomes of SNHL and $\mathrm{NC} / \mathrm{NL}$. Irrespective of the efficacy of furosemide in premature infants, the existing literature on safety outcomes depends almost entirely on observational data. Furthermore, few studies used analytic approaches to control for confounding causes of additional risk of SNHL and NC/NL on premature infants exposed to furosemide. The strength of evidence for the association of SNHL and NC/NL and furosemide is therefore determined to be low. Further randomized controlled trials with robust safety measures, such as the ongoing PTN trial, are urgently needed to assess the safety of furosemide in premature infants.

\section{Additional file}

Additional file 1: Data Abstraction Form. (DOCX $14 \mathrm{~kb}$ )

\section{Abbreviations \\ ABR: Auditory brain stem response; AHRQ: Agency for Healthcare Research and Quality; BAER: Brainstem auditory evoked response; \\ BPD: Bronchopulmonary dysplasia; FDA: Food and Drug Administration; NC: Nephrocalcinosis; NICU: Neonatal intensive care unit; NL: Nephrolithiasis; OAE: Otoacoustic emission test; PTN: Pediatric Trials Network; \\ SNHL: Sensorineural hearing loss}

\section{Acknowledgements}

Not applicable.

Funding

No external funding was obtained for this study.

Availability of data and materials

Not applicable.

Authors' contributions

WJ and GT conducted the review, DS, PBS, STR and MML were major contributors in development of manuscript. All authors read and approved the final manuscript.

Ethics approval and consent to participate

Not applicable.

Consent for publication

Not applicable.

Competing interests

The authors declare that they have no competing interests. 


\section{Publisher's Note}

Springer Nature remains neutral with regard to jurisdictional claims in published maps and institutional affiliations.

\section{Author details}

'Division of Pediatrics, University of North Carolina at Chapel Hill, UNC Hospitals 101 Manning Dr. 4th Floor, Chapel Hill, NC CB 7596, USA. ${ }^{2}$ Division of Nephrology, Department of Pediatrics and Communicable Diseases, C.S. Mott Children's Hospital, University of Michigan, Ann Arbor, MI, USA. ${ }^{3}$ Duke Department of Pediatrics, Duke University Medical Center, Durham, NC, USA. ${ }^{4}$ Gillings School of Global Public Health, University of North Carolina at Chapel Hill, Chapel Hill, USA.

Received: 13 August 2018 Accepted: 23 October 2018 Published online: 19 November 2018

\section{References}

1. Marshall DD, Kotelchuck M, Young TE, Bose CL, Kruyer L, O'Shea TM. Risk factors for chronic lung disease in the surfactant era: a North Carolina population-based study of very low birth weight infants. North Carolina Neonatologists Association. Pediatrics. 1999;104(6):1345-50.

2. Oh W, Poindexter BB, Perritt R, Lemons JA, Bauer CR, Ehrenkranz RA, Stoll BJ, Poole K, Wright LL. Association between fluid intake and weight loss during the first ten days of life and risk of bronchopulmonary dysplasia in extremely low birth weight infants. J Pediatr. 2005;147(6):786-90.

3. Cristobal R, Oghalai JS. Hearing loss in children with very low birth weight: current review of epidemiology and pathophysiology. Arch Dis Child Fetal Neonatal Ed. 2008;93(6):F462-8.

4. Fawke J. Neurological outcomes following preterm birth. Semin Fetal Neonatal Med. 2007:12(5):374-82.

5. Wigand $M E$, Heidland $A$. Ototoxic side-effects of high doses of frusemide in patients with uraemia. Postgrad Med J. 1971;47(Suppl):54-6.

6. Schwartz GH, David DS, Riggio RR, Stenzel KH, Rubin AL. Ototoxicity induced by furosemide. N Engl J Med. 1970;282(25):1413-4.

7. Brown CB, Ogg CS, Cameron JS, Bewick M. High dose frusemide in acute reversible intrinsic renal failure. A preliminary communication. Scott Med J. 1974:19(Suppl 1):35-9.

8. Rybak LP. Furosemide ototoxicity: clinical and experimental aspects. Laryngoscope. 1985:95(9 Pt 2 Suppl 38):1-14.

9. Iwamoto LM, Fujiwara N, Nakamura KT, Wada RK. Na-K-2Cl cotransporter inhibition impairs human lung cellular proliferation. Am J Physiol Lung Cell Mol Physiol. 2004;287(3):L510-4

10. Myracle MR, McGahan JP, Goetzman BW, Adelman RD. Ultrasound diagnosis of renal calcification in infants on chronic furosemide therapy. J Clin Ultrasound. 1986;14(4):281-7.

11. Schell-Feith EA, Kist-van Holthe JE, van der Heijden AJ. Nephrocalcinosis in preterm neonates. Pediatr Nephrol. 2010;25(2):221-30.

12. Campfield T, Braden G. Urinary oxalate excretion by very low birth weight infants receiving parenteral nutrition. Pediatrics. 1989;84(5):860-3.

13. Kamitsuka MD, Peloquin D. Renal calcification after dexamethasone in infants with bronchopulmonary dysplasia. Lancet. 1991;337(8741):626.

14. Abstrackr. http://abstrackr.cebm.brown.edu. Accessed 3 Oct 2018.

15. Higgins JP, Altman DG, Gotzsche PC, Juni P, Moher D, Oxman AD, Savovic J, Schulz KF, Weeks L, Sterne JA. The Cochrane Collaboration's tool for assessing risk of bias in randomised trials. BMJ. 2011;343:d5928.

16. Sterne JA, Hernan MA, Reeves BC, Savovic J, Berkman ND, Viswanathan M, Henry D, Altman DG, Ansari MT, Boutron I, et al. ROBINS-I: a tool for assessing risk of bias in non-randomised studies of interventions. BMJ. 2016;355:14919.

17. Owens DK, Lohr KN, Atkins D, Treadwell JR, Reston JT, Bass EB, Chang S, Helfand M. AHRQ series paper 5: grading the strength of a body of evidence when comparing medical interventions--agency for healthcare research and quality and the effective health-care program. J Clin Epidemiol. 2010;63(5):513-23.

18. McCann EM, Lewis K, Deming DD, Donovan MJ, Brady JP. Controlled trial of furosemide therapy in infants with chronic lung disease. J Pediatr. 1985; 106(6):957-62.

19. Mjoen S, Langslet A, Tangsrud SE, Sundby A. Auditory brainstem responses (ABR) in high-risk neonates. Acta Paediatr Scand. 1982;71(5):711-5.

20. Salamy A, Eldredge L, Tooley WH. Neonatal status and hearing loss in high-risk infants. J Pediatr. 1989;114(5):847-52.
21. Brown DR, Watchko JF, Sabo D. Neonatal sensorineural hearing loss associated with furosemide: a case-control study. Dev Med Child Neurol. 1991;33(9):816-23.

22. Borradori C, Fawer CL, Buclin T, Calame A. Risk factors of sensorineural hearing loss in preterm infants. Biol Neonate. 1997;71(1):1-10.

23. Ertl T, Hadzsiev K, Vincze O, Pytel J, Szabo I, Sulyok E. Hyponatremia and sensorineural hearing loss in preterm infants. Biol Neonate. 2001;79(2):109-12.

24. Rais-Bahrami K, Majd M, Veszelovszky E, Short BL. Use of furosemide and hearing loss in neonatal intensive care survivors. Am J Perinatol. 2004;21(6): 329-32.

25. Xoinis K, Weirather Y, Mavoori H, Shaha SH, Iwamoto LM. Extremely low birth weight infants are at high risk for auditory neuropathy. J Perinatol. 2007;27(11):718-23

26. Coenraad S, Goedegebure A, van Goudoever JB, Hoeve LJ. Risk factors for auditory neuropathy spectrum disorder in NICU infants compared to normal-hearing NICU controls. Laryngoscope. 2011;121(4):852-5.

27. Martinez-Cruz CF, Garcia Alonso-Themann P, Poblano A, Ochoa-Lopez JM. Hearing loss, auditory neuropathy, and neurological co-morbidity in children with birthweight <750 g. Arch Med Res. 2012;43(6):457-63.

28. Rastogi S, Mikhael M, Filipov P, Rastogi D. Effects of ventilation on hearing loss in preterm neonates: nasal continuous positive pressure does not increase the risk of hearing loss in ventilated neonates. Int J Pediatr Otorhinolaryngol. 2013;77(3):402-6.

29. Wang CH, Yang CY, Lien R, Chu SM, Hsu JF, Fu RH, Chiang MC. Prevalence and independent risk factors for hearing impairment among very low birth weight infants. Int J Pediatr Otorhinolaryngol. 2017;93:123-7.

30. Hufnagle KG, Khan SN, Penn D, Cacciarelli A, Williams P. Renal calcifications: a complication of long-term furosemide therapy in preterm infants. Pediatrics. 1982;70(3):360-3.

31. Woolfield N, Haslam R, Le Quesne G, Chambers HM, Hogg R, Jureidini K Ultrasound diagnosis of nephrocalcinosis in preterm infants. Arch Dis Child. 1988:63(1):86-8.

32. Jacinto JS, Modanlou HD, Crade M, Strauss AA, Bosu SK. Renal calcification incidence in very low birth weight infants. Pediatrics. 1988;81(1):31-5.

33. Ezzedeen F, Adelman RD, Ahlfors CE. Renal calcification in preterm infants: pathophysiology and long-term sequelae. J Pediatr. 1988;113(3):532-9.

34. Short A, Cooke RW: The incidence of renal calcification in preterm infants. Arch Dis Child 1991, 66(4 Spec No):412-417.

35. Downing GJ, Egelhoff JC, Daily DK, Alon U. Furosemide-related renal calcifications in the premature infant. A longitudinal ultrasonographic study. Pediatr Radiol. 1991;21(8):563-5.

36. Downing GJ, Egelhoff JC, Daily DK, Thomas MK, Alon U. Kidney function in very low birth weight infants with furosemide-related renal calcifications at ages 1 to 2 years. J Pediatr. 1992;120(4 Pt 1):599-604.

37. Stafstrom CE, Gilmore HE, Kurtin PS. Nephrocalcinosis complicating medical treatment of posthemorrhagic hydrocephalus. Pediatr Neurol. 1992:8(3):179-82.

38. Pope JC, Trusler LA, Klein AM, Walsh WF, Yared A, Brock JW 3rd. The natural history of nephrocalcinosis in premature infants treated with loop diuretics. J Urol. 1996;156(2 Pt 2):709-12.

39. Saarela T, Vaarala A, Lanning P, Koivisto M. Incidence, ultrasonic patterns and resolution of nephrocalcinosis in very low birthweight infants. Acta Paediatr. 1999:88(6):655-60

40. Schell-Feith EA, Kist-van Holthe JE, Conneman N, van Zwieten PH, Holscher $\mathrm{HC}$, Zonderland HM, Brand R, van der Heijden BJ. Etiology of nephrocalcinosis in preterm neonates: association of nutritional intake and urinary parameters. Kidney Int. 2000;58(5):2102-10.

41. Narendra A, White MP, Rolton HA, Alloub Zl, Wilkinson G, McColl JH, Beattie J. Nephrocalcinosis in preterm babies. Arch Dis Child Fetal Neonatal Ed. 2001;85(3):F207-13.

42. Hoppe B, Duran I, Martin A, Kribs A, Benz-Bohm G, Michalk DV, Roth B. Nephrocalcinosis in preterm infants: a single center experience. Pediatr Nephrol. 2002;17(4):264-8.

43. Hein G, Richter D, Manz F, Weitzel D, Kalhoff H. Development of nephrocalcinosis in very low birth weight infants. Pediatr Nephrol. 2004;19(6):616-20

44. Ketkeaw K, Thaithumyanon P, Punnahitananda S. Nephrocalcinosis in very low birth weight infants: a single center experience. J Med Assoc Thail. 2004;87(Suppl 2):S72-7.

45. Cranefield DJ, Odd DE, Harding JE, Teele RL. High incidence of nephrocalcinosis in extremely preterm infants treated with dexamethasone. Pediatr Radiol. 2004;34(2):138-42. 
46. Gimpel C, Krause A, Franck P, Krueger M, von Schnakenburg C. Exposure to furosemide as the strongest risk factor for nephrocalcinosis in preterm infants. Pediatr Int. 2010;52(1):51-6.

47. Chang HY, Hsu CH, Tsai JD, Li ST, Hung HY, Kao HA, Chang JH, Chung HY, Wang HK. Renal calcification in very low birth weight infants. Pediatr Neonatol. 2011;52(3):145-9.

48. Lee HS, Sung IK, Kim SJ, Youn YA, Lee JY, Lim GY, Im SA, Ku YM, Lee JH, Kim SY. Risk factors associated with nephrocalcinosis in preterm infants. Am J Perinatol. 2014;31(4):279-86.

49. Mohamed GB, Ibrahiem MA, Abdel Hameed WM. Nephrocalcinosis in preterm neonates: a study of incidence and risk factors. Saudi J Kidney Dis Transpl. 2014;25(2):326-32.

50. Stewart A, Brion LP. Intravenous or enteral loop diuretics for preterm infants with (or developing) chronic lung disease. Cochrane Database Syst Rev. 2011;(9):Cd001453.

51. Hsieh EM, Hornik CP, Clark RH, Laughon MM, Benjamin DK Jr, Smith PB. Medication use in the neonatal intensive care unit. Am J Perinatol. 2014; 31(9):811-21.

52. Laughon MM, Chantala K, Aliaga S, Herring AH, Hornik CP, Hughes R, Clark RH, Smith PB. Diuretic exposure in premature infants from 1997 to 2011. Am J Perinatol. 2015:32(1):49-56.

53. Viswanathan S, Khasawneh W, McNelis K, Dykstra C, Amstadt R, Super DM, Groh-Wargo S, Kumar D. Metabolic bone disease: a continued challenge in extremely low birth weight infants. JPEN J Parenter Enteral Nutr. 2014;38(8): 982-90.

54. Jensen EA, White AM, Liu P, Yee K, Waber B, Monk HM, Zhang H. Determinants of severe metabolic bone disease in very low-birth-weight infants with severe bronchopulmonary dysplasia admitted to a tertiary referral center. Am J Perinatol. 2016;33(1):107-13.

55. Shankaran S, Liang KC, llagan N, Fleischmann L. Mineral excretion following furosemide compared with bumetanide therapy in premature infants. Pediatr Nephrol. 1995;9(2):159-62.

56. Stalnaker KA, Poskey GA. Osteopenia of prematurity: does physical activity improve bone mineralization in preterm infants? Neonatal Netw. 2016;35(2): 95-104.

57. Ukarapong S, Venkatarayappa SKB, Navarrete C, Berkovitz G. Risk factors of metabolic bone disease of prematurity. Early Hum Dev. 2017;112:29-34.

58. Cediel G, Pacheco-Acosta J, CastiUo-Durdn C. Vitamin D deficiency in pediatric clinical practice. Arch Argent Pediatr. 2018;116(1):e75-81.

59. Rustico SE, Calabria AC, Garber SJ. Metabolic bone disease of prematurity. J Clin Transl Endocrinol. 2014;1(3):85-91.

60. Kearns GL, Abdel-Rahman SM, Alander SW, Blowey DL, Leeder JS, Kauffman RE. Developmental pharmacology--drug disposition, action, and therapy in infants and children. N Engl J Med. 2003;349(12):1157-67.

61. Aranda JV, Perez J, Sitar DS, Collinage J, Portuguez-Malavasi A, Duffy B, Dupont C. Pharmacokinetic disposition and protein binding of furosemide in newborn infants. J Pediatr. 1978;93(3):507-11.

62. Peterson RG, Simmons MA, Rumack BH, Levine RL, Brooks JG. Pharmacology of furosemide in the premature newborn infant. J Pediatr. 1980;97(1):139-43.

63. Vert $P$, Broquaire $M$, Legagneur M, Morselli PL. Pharmacokinetics of furosemide in neonates. Eur J Clin Pharmacol. 1982;22(1):39-45.

64. Mirochnick MH, Miceli JJ, Kramer PA, Chapron DJ, Raye JR. Furosemide pharmacokinetics in very low birth weight infants. J Pediatr. 1988;112(4): 653-7.

65. Laughon MM, Benjamin DK Jr, Capparelli EV, Kearns GL, Berezny K, Paul IM, Wade K, Barrett J, Smith PB, Cohen-Wolkowiez M. Innovative clinical trial design for pediatric therapeutics. Expert Rev Clin Pharmacol. 2011; 4(5):643-52

66. Rodriguez W, Selen A, Avant D, Chaurasia C, Crescenzi T, Gieser G, Di Giacinto J, Huang SM, Lee $P$, Mathis L, et al. Improving pediatric dosing through pediatric initiatives: what we have learned. Pediatrics. 2008;121(3): 530-9.

67. Safety of furosemide in premature infants at risk of bronchopulmonary dysplasia. https://clinicaltrials.gov/ct2/show/NCT02527798. Accessed 21 June 2018.

68. Abitbol CL, Rodriguez MM. The long-term renal and cardiovascular consequences of prematurity. Nat Rev Nephrol. 2012;8(5):265-74.

69. Bixler GM, Powers GC, Clark RH, Walker MW, Tolia VN. Changes in the diagnosis and Management of Patent Ductus Arteriosus from 2006 to 2015 in United States neonatal intensive care units. J Pediatr. 2017;189:105-12.
70. Soll RF, Edwards EM, Badger GJ, Kenny MJ, Morrow KA, Buzas JS, Horbar JD. Obstetric and neonatal care practices for infants 501 to $1500 \mathrm{~g}$ from 2000 to 2009. Pediatrics. 2013;132(2):222-8.

71. Liberati A, Altman DG, Tetzlaff J, Mulrow C, Gotzsche PC, loannidis JP, Clarke M, Devereaux PJ, Kleijnen J, Moher D. The PRISMA statement for reporting systematic reviews and meta-analyses of studies that evaluate health care interventions: explanation and elaboration. PLoS Med. 2009;6(7):e1000100.
Ready to submit your research? Choose BMC and benefit from:

- fast, convenient online submission

- thorough peer review by experienced researchers in your field

- rapid publication on acceptance

- support for research data, including large and complex data types

- gold Open Access which fosters wider collaboration and increased citations

- maximum visibility for your research: over $100 \mathrm{M}$ website views per year

At BMC, research is always in progress.

Learn more biomedcentral.com/submissions 